\title{
Role of steric interactions in the delta opioid receptor selectivity of $\left[D-P^{2}{ }^{2}\right.$, D-Pen ${ }^{5}$ ]enkephalin
}

\author{
HENRY I. MOSBERG, RONALD C. HAASETH, KONDAREDDIAR RAMALINGAM, \\ ALFRED MANSOUR*, HUDA AKIL* and RONALD W. WOODARD \\ College of Pharmacy and ${ }^{*}$ Mental Health Research Institute, University of Michigan, Ann Arbor, MI, \\ USA
}

Received 14 July, accepted for publication 23 November 1987

\begin{abstract}
In order to assess the individual effects of each of the 3-methyl groups in residue 2 of [D-Pen ${ }^{2}, \mathrm{D}-\mathrm{Pen}^{5}$ ]enkephalin on binding affinity to mu and delta opioid receptors, $(2 S, 3 S)$ methylcysteine $((3 S) \mathrm{Me}-\mathrm{D}-\mathrm{Cys})$ and $(2 S, 3 R)$ methylcysteine $((3 R) \mathrm{Me}-\mathrm{D}-\mathrm{Cys})$ were synthesized and incorporated into the analogs, $\left[(3 S) \mathrm{Me}-\mathrm{D}-\mathrm{Cys}{ }^{2}, \mathrm{D}-\mathrm{Pen}^{5}\right] \mathrm{enke-}$ phalin and [(3R)Me-D-Cys $\left.{ }^{2}, \mathrm{D}-\mathrm{Pen}^{5}\right]$ enkephalin. Of these analogs, [(3S)Me-D-Cys ${ }^{2}$, D-Pen ${ }^{5}$ ]enkephalin appears from ${ }^{1} \mathrm{H}$ n.m.r. spectra to assume a conformation similar to those of $\left[\mathrm{D}-\mathrm{Pen}^{2}, \mathrm{D}-\mathrm{Pen}^{5}\right]$ enkephalin and the less delta receptor-selective, but more potent, $\left[\mathrm{D}-\mathrm{Cys}^{2}, \mathrm{D}-\mathrm{Pen}^{5}\right]$ enkephalin. Assessment of binding affinity to $\mathrm{mu}$ and delta receptors revealed that $\left[(3 S) \mathrm{Me}-\mathrm{D}-\mathrm{Cys}{ }^{2}, \mathrm{D}-\mathrm{Pen}^{5}\right]$ enkephalin exhibits delta receptor affinity intermediate between [D-Pen $\left.{ }^{2}, \mathrm{D}-\mathrm{Pen}^{5}\right]$ enkephalin and $\left[\mathrm{D}-\mathrm{Cys}{ }^{2}, \mathrm{D}-\mathrm{Pen}{ }^{5}\right] \mathrm{enke}-$ phalin, while its mu receptor affinity is similar to that of $\left[\mathrm{D}-\mathrm{Cys}^{2}, \mathrm{D}-\mathrm{Pen}^{5}\right]$ enkephalin. These results suggest that, for $\left[\mathrm{D}-\mathrm{Pen}^{2}, \mathrm{D}-\mathrm{Pen}^{5}\right]$ enkephalin, adverse steric interactions between the D-Pen ${ }^{2}$ pro- $R$ methyl group and the mu receptor binding site lead to the low $\mathrm{mu}$ receptor binding affinity observed for this analog. By contrast, both the pro- $R$ and pro-S D-Pen ${ }^{2}$ methyl groups lead to minor steric interactions which contribute to the somewhat lower delta receptor affinity of this compound.
\end{abstract}

Key words: enkephalins; ' H n.m.r.; steric effects; structure-activity; structure-selectivity

Abbreviations recommended by IUPAC-IUB Commission of Biochemical Nomenclature have been used. Other abbreviations: Pen, penicillamine; ${ }^{1} \mathrm{H}$ n.m.r., proton nuclear magnetic resonance spectroscopy; $t$-Leu, tert.-Leucine; Abu, 2-aminobutyric acid; (3S)Me-Dcysteine, (2S,3S)methylcysteine; (3R)Me-D-cysteine, (2S,3R)methylcysteine; DMF, dimethylformamide; HMPA, hexamethylphosphoramide; HPLC, high performance liquid chromatography; TSP, 3-(trimethylsilyl)propionic acid; TFA, trifluoroacetic acid; DAGO, $\left[\mathrm{D}-\mathrm{Ala}^{2}, \mathrm{NMePhe}^{4}, \mathrm{Gly}^{5}\right.$-ol]enkephalin; DPDPE, [D$\mathrm{Pen}^{2}, \mathrm{D}-\mathrm{Pen}^{5}$ ]enkephalin.
We have previously described (1-3) a series of cyclic, penicillamine-containing enkephalin analogs of the general structure:

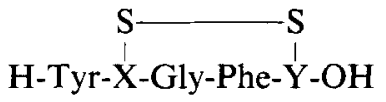

in which

$$
\begin{aligned}
& \mathrm{X}=\mathrm{D} \text {-Cys or } \quad \text { D-Pen } \\
& \mathrm{Y}=\mathrm{D} \text { (or } \mathrm{L} \text { )-Cys } \text { or } \mathrm{D}(\text { or } \mathrm{L} \text { )-Pen }
\end{aligned}
$$


where Pen, penicillamine, is 3,3-dimethylcysteine. These analogs, which are conformationally restricted by virtue of cyclization via the disulfide and are further rigidized due to the gem dimethyl substituents of the penicillamine residue(s), are notable for their high degree of selectivity for the delta opioid receptor over the mu opioid receptor. Within this series, the bis-penicillamine analogs display the highest selectivity yet reported for the delta receptor, while those analogs with a single penicillamine residue are less selective but are in general more potent. While some conformational differences are observed between members of this series, they appear to share a similar overall topography (4). Of particular note is the similarity of conformation-dependent ' $\mathrm{H}$ n.m.r. parameters for the analogs, [D-Cys ${ }^{2}, \mathrm{D}-\mathrm{Pen}^{5}$ ] enkephalin and [D-Pen ${ }^{2}$, D-Pen ${ }^{5}$ enkephalin (DPDPE)(4), the former of which is more potent but less delta receptor selective than is the latter. These results suggest that the penicillamine 3 methyl groups at residue 2 lead to adverse steric interactions at delta and particularly at $\mathrm{mu}$ receptors and thus are responsible for the higher delta selectivity (and lower potency) of the bis-penicillamine analog. Further evidence of this effect comes from the finding that the binding affinity of [D-t-Leu ${ }^{2}, \mathrm{D}-\mathrm{t}-$ Leu ${ }^{5}$ enkephalin (a linear isostere of [D-Pen ${ }^{2}$, D-Pen ${ }^{5}$ enkephalin) is 450 -fold lower at $\mathrm{mu}$ receptors and 36 -fold lower at delta receptors than is the binding affinity of $\left[\mathrm{D}-\mathrm{Abu}^{2}, \mathrm{D}-\right.$ $\mathrm{t}$-Leu $\mathrm{u}^{5}$ ]enkephalin (a linear isostere of [DCys $^{2}$, D-Pen ${ }^{5}$ enkephalin) (5). Reasoning that each of the Pen' 3-methyl groups might well have different effects on binding. we prepared ( $2 S, 3 S)$ methylcysteine ((3S)Me-D-cysteine)
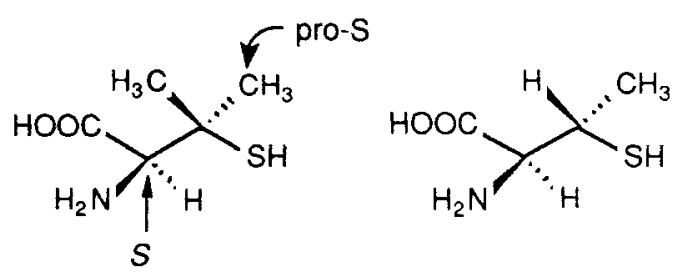

D-Penicillamine

(3S)-Me-D-Cysteine and $\quad(2 S, 3 R)$ methylcysteine $\quad((3 R) \mathrm{Me}-\mathrm{D}-$ cysteine) (Fig. 1) and utilized these for the synthesis of $[(3 S) \mathrm{Me}-\mathrm{D})-\mathrm{Cys}^{2}$, D-Pen $\left.{ }^{5}\right]$ enkephalin and $\left[(3 R) \mathrm{Me}-\mathrm{D}-\mathrm{Cys}^{2}, \mathrm{D}-\mathrm{Pen}^{5}\right]$ enkephalin. Evaluation of the opioid receptor binding profiles of these analogs and measurement of conformation-dependent ${ }^{\prime} \mathrm{H}$ n.m.r. parameters indicate that, indeed, each of the Pen ${ }^{2} 3$-methyl groups of [D-Pen ${ }^{2}$, DPen'] enkephalin has a different effect on binding to $\mathrm{mu}$ and delta opioid receptors.

\section{MATERIALS AND METHODS}

Synthesis of (3S) Me-D-Cys and (3R) Me-DCys. (3S)Me-D-cysteine and $(3 R)$ Me-D-cysteine were prepared by modifications of known routes or by extensions of standard methodologies. (3S)Me-D-cysteine was prepared from allo- $\mathrm{V}$-Boc- $\mathrm{O}$-tosyl-D-threonine methyl ester (allo-D-threonine having been obtained from $D$-threonine by the procedure of Elliot (6)) by displacement of the tosylate moiety with potassium thiolacetate (7) followed by deprotection. ( $3 R$ ) Me$D$-cysteine was prepared in a similar fashion starting from threo- $\mathrm{V}$-Boc- $\mathrm{O}$-tosyl-D-threonine methyl ester. The $S_{N} 2$ displacement of the tosylate by the thiolacetate anion in the first case proceeded without any elimination, $O$-alkylation of thiolacetate, or $\mathrm{S}_{\mathrm{N}} 1$-type mechanism. However. considerable elimination occurred in the latter as marked by the formation of methyl N-Boc-Z-amino crotonate. The elimination process was limited to ca. $40 \%$ by proper choice of solvent and temperature. Prior to their use in solid phase peptide synthesis, both $(3 R) \mathrm{Me}-\mathrm{D}$ -

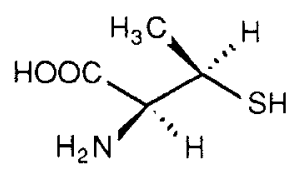

FIGURE 1

Structures of $(3 R) \mathrm{Me}-\mathrm{D}-$ cysteine. (3S)Me-i)-cysteine, and 1 -penicillamine 
cysteine and $(3 S) \mathrm{Me}$-D-cysteine were converted to the $S$ - $p$-methylbenzyl- $N$-Boc derivatives by standard methods.

D-Threonine methyl ester hydrochloride (1). Dry $\mathrm{HCl}$ gas was passed through a suspension of $\mathrm{D}$-threonine in methanol at $0^{\circ}$ until the solid dissolved. The reaction was left overnight and the solvent was then removed under vacuum to give the title compound as a white solid in $94 \%$ yield. The ester was used without further purification.

$\mathrm{N}$-Benzoyl-D-threonine methyl ester (2). The methyl ester 1 was benzoylated according to the procedure of Elliot (6) by adding benzoyl chloride dropwise to ester $\mathbf{1}$ dissolved in dioxane-water while maintaining the $\mathrm{pH}$ at $8.8-9.0$ with $5 \mathrm{~N} \mathrm{NaOH}$. After removal of the dioxane, the aqueous phase was extracted with ethyl acetate. After drying over $\mathrm{MgSO}_{4}$, the ethyl acetate was removed to afford 2 , which was recrystallized from benzene to give a $65 \%$ yield of pure 2 , m.p. $93-94^{\circ}$.

N-Boc-D-threonine methyl ester (3). The methyl ester 1 was dissolved in a $\mathrm{Na}_{2} \mathrm{CO}_{3}$ solution (dioxane/water. 2:1) at $0^{\circ}$ and treated with di-tert.-butyl dicarbonate according to standard literature protocol (8) to give the title threonine derivative in $86 \%$ yield as an oil which was used, without further purification, in the next step.

$\mathrm{N}$-Boc-O-tosyl-D-threonine methyl ester (4). To compound 3 dissolved in pyridine and cooled to $0^{\circ}$ was added solid tosyl chloride in portions. The reaction was allowed to stand overnight and was then poured into ice water. The oil that formed was extracted with diethyl ether. The combined ether fractions were washed with $0.5 \mathrm{~N} \mathrm{HCl}$, water, and saturated $\mathrm{Na}_{2} \mathrm{CO}_{3}$. Evaporation of the diethyl ether, after drying over $\mathrm{MgSO}_{4}$, afforded crude 4 in $80 \%$ yield. The crude tosylate was purified on silica gel with first 9:1 and then $7: 3$, hexane:ethyl acetate. Evaporation of the fractions containing the tosylate gave $70 \%$ of 4 as a clear, viscous oil.
Methyl cis-D-phenyl-5-methyl- $\Delta^{2}$-oxazoline-4carboxylate (5). Treatment of compound 2 with thionyl chloride at $0^{\circ}$ for $2 \mathrm{~h}$ gave, after removal of excess thionyl chloride at $35^{\circ}$ under reduced pressure, an oily residue. This residue was dissolved in chloroform and poured slowly with stirring into a $10 \%$ $\mathrm{Na}_{2} \mathrm{CO}_{3}$ solution (care was taken to maintain a basic $\mathrm{pH}$ of the solution). The chloroform layer was separated, dried, and the solvent removed under reduced pressure to yield the title compound ( $87 \%$ yield) which solidified on standing. Crystallization of a small portion from petroleum ether gave a pure sample of 5, m.p. $75-76^{\circ}$ [lit. 74-75 (6)].

allo-D-Threonine (6). Crude 5 was hydrolyzed by heating in $6 \mathrm{~N} \mathrm{HCl}$ at $95^{\circ}$ for $5 \mathrm{~h}$ followed by cooling to room temperature, filtering off the benzoic acid precipitate, and evaporating the aqueous filtrate. The resulting syrup was purified by cation exchange chromotography to give allo-D-threonine in $69 \%$ yield based on 2. M.p. $274-276^{\circ}$ (lit. $276-280^{\circ}(7)$ ), $[\alpha]_{D}^{25}$ $32.0^{\circ}(c 8,1 \mathrm{~N} \mathrm{HCl})\left[\right.$ lit. $[\alpha]_{\mathrm{D}}^{27} 32.5^{\circ}(c 8.2,1 \mathrm{~N}$ $\mathrm{HCl})(7)]$.

allo-N-Boc-O-tosyl-D-threonine methyl ester (7). Compound 7, also an oil, was prepared from 6 by the methods described above for the preparation of the diastereomer, 4 .

(3S) Me-D-cysteine (8). Compound 8 was prepared in $51 \%$ overall yield by treatment of 7 with potassium thiolacetate in DMF overnight at room temperature followed by hydrolysis of the crude S-acetylamino acid product in refluxing $12 \mathrm{~N} \mathrm{HCl}$ for $5 \mathrm{~h} \mathrm{(7)} \mathrm{to}$ give the crude amino acid in $75 \%$ yield. The target compound was further purified via cation exchange chromotography to give pure 8 in $65 \%$ yield. M.p. $204-206^{\circ}$ [lit. m.p. $\left.206-208^{\circ}(9)\right],[\alpha]_{\mathrm{D}}^{25}-45.0^{\circ}(c 1,1 \mathrm{~N} \mathrm{HCl})\{$ lit. $[\alpha]_{D}^{19}-41.4^{\circ}(c 1,1 \mathrm{~N} \mathrm{HCl})(7) ;[\alpha]_{D}^{25}-45.0^{\circ}$ $(c 1,1 \mathrm{~N} \mathrm{HCl})(9)\}$.

(3R) Me-D-cysteine (9). Compound 9 was prepared from 4 in a manner similar to that for 8 except HMPA was used as solvent. The methyl $N$-Boc- $Z$-aminocrotonate impurity 
( $\approx 40 \%$ of a $90 \%$ total yield) was removed from the S-acetyl derivative by silica gel chromatography to yield after hydrolysis the title compound in $49 \%$ yield based on 4. M.p. $146-149^{\circ} \quad$ [lit. m.p. 147-153 ${ }^{\circ}$ (9)], $[\alpha]_{\mathrm{D}}^{25}=13.0^{\circ}(c 1,1 \mathrm{~N} \mathrm{HCl})\left\{\right.$ lit.: $[x]_{\mathrm{D}}^{25}=13.5^{\circ}$ (c $1,1 \mathrm{~N} \mathrm{HCl})(9)\}$.

S-p-Methylbenzyl-(3R)Me-D-cysteine (10). Amino acid 9 was treated with sodium-liquid ammonia to give the sodium salt of the thio amino acid which was alkylated with $p$ methylbenzyl bromide directly in the liquid ammonia solution. Evaporation of the ammonia gave the S-protected amino acid which was purified by crystallization from acetic acid-water to give the title compound in $55 \%$ yield. M.p. $185-187^{\circ},[x]_{D}^{25}=47.5^{\circ}(c$ $1,0.1 \mathrm{~N} \mathrm{HCl}$ ).

S-p-Methylbenzyl-(3S) Me-D-cysteine

Amino acid $\mathbf{8}$ was aklylated with $p$-methylbenzyl bromide to give the title compound in $60 \%$ yield. M.p. $177-178^{\circ},[\alpha]_{\mathrm{D}}^{25}=-83.9^{\circ}(\mathrm{c}$ $1,1 \mathrm{~N} \mathrm{HCl}$ ).

N-Boc-S-p-Methylbenzyl-(3R)Me-D-cysteine (12). The S-protected cysteine analog 10 was converted into the $N$-Boc derivative, an oil, by standard procedures, described above for 3 , in $63 \%$ yield.

N-Boc-S-p-Methylbenzyl-(3S)Me-D-cysteine (13). The title compound was prepared from 11 by the method described for the preparation of 12. M.p. $150-151^{\circ},[x]_{\mathrm{D}}^{25}=-104.2^{\circ}$ (c 1,95\% ethanol).

Peptide synthesis. [(3S)Me-D-Cys ${ }^{2}$, DPen $\left.{ }^{5}\right]$ enkephalin and $\left[(3 R) \mathrm{Me}-\mathrm{D}-\mathrm{Cys}^{2}, \mathrm{D}-\right.$ $P^{5} n^{5}$ ]enkephalin were synthesized by solid phase methods as previously reported for the related $D-P e n^{2}$ and $D-C y s^{2}$ analogs $(2,3)$. Purification was effected by semipreparative HPLC on a Vydac 218TP C-18 column $(2.5 \mathrm{~cm} \times 22 \mathrm{~cm})$ with the solvent system $0.1 \%$ TFA in $\mathrm{H}_{2} \mathrm{O} / 0.1 \%$ TFA in acetonitrile, using a $0-50 \%$ gradient of organic component. Purity of both peptides was greater than $99 \%$ as assessed by analytical HPLC monitored at both $280 \mathrm{~nm}$ and $230 \mathrm{~nm}$.
${ }^{\prime} H$ n.m.r. ${ }^{1} \mathrm{H}$ n.m.r. experiments were performed on an IBM WP270SY spectrometer operating at $270 \mathrm{MHz}$. Samples were prepared by dissolving the appropriate peptide in $100.0 \% \mathrm{D}_{2} \mathrm{O}$ (Aldrich, Milwaukee, WI) or in $90 \% \mathrm{H}_{2} \mathrm{O} / 10 \% \mathrm{D}_{2} \mathrm{O}$ and adjusting the $\mathrm{pH}$ to 3 (uncorrected meter reading) with $\mathrm{CD}_{3} \mathrm{COOD}$. Samples used for experiments in $100.0 \% \quad \mathrm{D}_{2} \mathrm{O}$ were previously dissolved in $\mathrm{D}_{2} \mathrm{O}$ and lyophilized to replace exchangeable protons with deuterons. Final concentrations of peptides were approximately $10 \mathrm{~mm} .{ }^{1} \mathrm{H}$ n.m.r. spectra were obtained via accumulations of one-pulse experiments utilizing a $60^{\circ}$ pulse. Presaturation of the water resonance was employed for samples in $\mathrm{H}_{2} \mathrm{O} / \mathrm{D}_{2} \mathrm{O}$ mixtures. Resonances arising from individual residues in each peptide were determined by homonuclear decoupling experiments. Chemical shifts are reported as ppm downfield of internal TSP.

Opioid receptor binding assays. Selective, radioactive opioid peptides were used to label $\mathrm{mu}$ versus delta opioid receptors in brain sections and to evaluate binding profiles. Male Sprague-Dawley rats were sacrificed by decapitation and their brains were quickly removed and frozen in liquid isopentane $\left(-30^{\circ}\right)$ for $30 \mathrm{~s}$. Frozen brains were sectioned in a bright Cryostat $(25 \mu \mathrm{m})$ and thawmounted on precleaned, gelatin-coated microscope slides. The brain sections were then dried overnight at $4^{\circ}$ under reduced pressure in a glass desiccator and stored at $-80^{\circ}$. The slide-mounted sections were gradually brought to room temperature immediately prior to use, and were incubated with $200 \mu \mathrm{L}$ of $\left[{ }^{3} \mathrm{H}\right]$ ligand in chambers designed to maintain ambient temperature $\left(25^{\circ}\right)$ and humidity $(60-80 \%)$. The slides were incubated for $60 \mathrm{~min}$, drained, and washed in four consecutive $250-\mathrm{mL}$ washes of $50 \mathrm{~mm}$ Tris $(\mathrm{pH} 7.6$, $4^{\circ}$ ). Slides incubated with the highly $\mathrm{mu}$ opioid receptor selective ligand $\left[{ }^{3} \mathrm{H}\right]\left[\mathrm{D}-\mathrm{Ala}^{2}\right.$, NMePhe ${ }^{4}, G_{1}{ }^{5}$-ol $]$ en kephalin $\left(\left[{ }^{3} \mathrm{H}\right] \mathrm{DAGO}\right)$ (10) were given four 1-min washes, while those incubated with the delta receptor selective $\left[{ }^{3} \mathrm{H}\right]\left[\mathrm{D}-\mathrm{Pen}^{2}, \quad\right.$ D-Pen $\left.{ }^{5}\right]$ enkephalin $\left.\left({ }^{3} \mathrm{H}\right] \mathrm{DPDPE}\right)$ were given four 2-min washes. Concentrations of radioligand used were 
$0.9 \mathrm{~nm}$ for $\left[{ }^{3} \mathrm{H}\right] \mathrm{DAGO}$ and $7.5 \mathrm{~nm}$ for $\left[{ }^{3} \mathrm{H}\right] \mathrm{DPDPE}$. Following the Tris washes, all slides were rinsed with $250 \mathrm{~mL}$ distilled water $\left(4^{\circ}\right)$ and quickly dried with a portable hair dryer. Nonspecific binding was evaluated by treating a parallel set of slides with the same concentrations of $\left[{ }^{3} \mathrm{H}\right]$ ligand with a $1 \mu \mathrm{M}$ final concentration of an unlabeled competitor: levorphanol to displace $\left[{ }^{3} \mathrm{H}\right] \mathrm{DAGO}$ and either Tyr-D-Ser-Gly-Phe-Leu-Thr (DSLET) (11) or DPDPE to displace $\left[{ }^{3} \mathrm{H}\right] \mathrm{DPDPE}$. Test compounds were evaluated over the concentration range $0.1 \mathrm{nM}$ to $10 \mu \mathrm{M}$. The binding was quantified by placing the brain sections into scintillation vials containing $10 \mathrm{~mL}$ scintillant and vigorously shaking for $30 \mathrm{~min}$. Each data point is an average of a minimum of two brain sections and $\mathrm{IC}_{50}$ values were calculated by using log-logit plots.

\section{RESULTS AND DISCUSSION}

Table 1 summarizes the binding affinities of $\left[\mathrm{D}-\mathrm{Pen}^{2}, \quad\right.$ D-Pen $\left.{ }^{5}\right]$ enkephalin, [D-Cys ${ }^{2}, \mathrm{D}-$ Pen $\left.{ }^{5}\right]$ enkephalin, [(3R)Me-D-Cys ${ }^{2}, \quad \mathrm{D}-$ Pen $\left.{ }^{5}\right]$ enkephalin and $\left[(3 S) \mathrm{Me}-\mathrm{D}-\mathrm{Cys}^{2}, \mathrm{D}-\right.$ $P^{5} n^{5}$ enkephalin to $\mathrm{mu}$ and delta opioid receptors, as measured by their abilities to displace radiolabeled ligands selective for $\mathrm{mu}$ $\left(\left[{ }^{3} \mathrm{H}\right] \mathrm{DAGO}(10)\right)$ and delta $\left(\left[{ }^{3} \mathrm{H}\right] \mathrm{DPDPE}(3)\right)$ receptors. As was previously observed, [D$\mathrm{Pen}^{2}, \mathrm{D}-\mathrm{Pen}^{5}$ ]enkephalin has lower affinity for delta and much lower affinity for mu receptors than does [D-Cys ${ }^{2}$, D-Pen ${ }^{5}$ ]enkephalin and as a result exhibits considerably higher delta receptor selectivity. The delta receptor binding affinities of both $\left[(3 R) \mathrm{Me}-\mathrm{D}-\mathrm{Cys}^{2}, \mathrm{D}-\right.$ Pen $\left.^{5}\right]$ enkephalin and $\left[(3 S) \mathrm{Me}-\mathrm{D}-\mathrm{Cys}^{2}\right.$, D$\mathrm{Pen}^{5}$ ]enkephalin are intermediate between those observed for [D-Pen ${ }^{2}$, D-Pen $\left.{ }^{5}\right]$ enkephalin and $\left[\mathrm{D}-\mathrm{Cys}^{2}, \mathrm{D}-\mathrm{Pen}^{5}\right]$ enkephalin. The $\mathrm{mu}$ receptor binding affinity of [ $(3 R) \mathrm{Me}-\mathrm{D}-$ $\left.\mathrm{Cys}^{2}, \quad \mathrm{D}-\mathrm{Pen}^{5}\right]$ enkephalin is intermediate between [D-Cys $\left.{ }^{2}, \mathrm{D}-\mathrm{Pen}^{5}\right]$ enkephalin and [D$\left.\mathrm{Pen}^{2}, \quad \mathrm{D}-\mathrm{Pen}^{5}\right]$ enkephalin although more similar to the former, and the mu receptor binding affinity of [(3S)Me-D-Cys ${ }^{2}$, D$\mathrm{Pen}^{5}$ ]enkephalin is quite similar to that observed for [D-Cys ${ }^{2}$, D-Pen $\left.{ }^{5}\right]$ enkephalin. It should be noted that none of the compounds listed in Table 1 displayed significant affinity for the kappa opioid receptor $\left(\mathrm{IC}_{50}>\right.$ $10000 \mathrm{~nm}$ ) as assessed by the displacement of $\left[{ }^{3} \mathrm{H}\right]$ bremazocine in the presence of $100 \mathrm{nM}$ DAGO and $100 \mathrm{~nm}$ DPDPE (used to block $\mathrm{mu}$ and delta binding sites, respectively).

The conformations of [D-Pen $\left.{ }^{2}, \mathrm{D}-\mathrm{Pen}^{5}\right]$ enkephalin and [D-Cys ${ }^{2}, \mathrm{D}-\mathrm{Pen}^{5}$ ]enkephalin appear to be quite similar (4) and differences in opioid receptor binding behavior for these analogs can be attributed to steric interactions between the Pen ${ }^{2} 3$-methyl groups and the receptor binding sites. However, the asymmetrically substituted 3-Me-D-Cys ${ }^{2}$ analogs might assume different conformations. In order to assess the relative contributions of conformational differences and steric interactions on the opioid receptor binding

TABLE 1

Opioid receptor binding profiles for 3-Me-D-Cys enkephalin analogs

\begin{tabular}{|c|c|c|c|}
\hline Analog & {$\left[{ }^{3} \mathrm{H}\right] \mathrm{DPDPE}$} & {$\left[{ }^{3} \mathrm{H}\right] \mathrm{DAGO}$} & $\frac{\mathrm{IC}_{50}(\mu)}{\mathrm{IC}_{50}(\delta)}$ \\
\hline$\left[\mathrm{D}-\mathrm{Pen}^{2}, \mathrm{D}-\mathrm{Pen}^{5}\right] \mathrm{E}$ & $18.4 \pm 3.9$ & $2230 \pm 131$ & 121 \\
\hline$\left[\mathrm{D}-\mathrm{Cys}^{2}, \mathrm{D}-\mathrm{Pen}^{5}\right] \mathrm{E}$ & $7.6 \pm 3.0$ & $22.2 \pm 2.3$ & 2.9 \\
\hline$\left[(3 S) \mathrm{Me}-\mathrm{D}-\mathrm{Cys} \mathrm{s}^{2}, \mathrm{D}-\mathrm{Pen}^{5}\right] \mathrm{E}$ & $13.7 \pm 6.1$ & $28.7 \pm 1.4$ & 2.1 \\
\hline$\left[(3 R) \mathrm{Me}-\mathrm{D}-\mathrm{Cys}{ }^{2}, \mathrm{D}-\mathrm{Pen}^{5}\right] \mathrm{E}$ & $13.3 \pm 3.5$ & $88.8 \pm 22.2$ & 6.7 \\
\hline
\end{tabular}

Binding studies were performed on rat brain slices incubated at $25^{\circ}$ in $50 \mathrm{~mm}$ Tris buffer at pH 7.6 . Radioligand concentrations were $7.5 \mathrm{~nm}$ for the delta selective ligand $\left[{ }^{3} \mathrm{H}\right] \mathrm{DPDPE}$ and $0.9 \mathrm{~nm}$ for the mu selective ligand $\left[{ }^{3} \mathrm{H}\right] \mathrm{DAGO}$.

*Values reported are $\mathrm{IC}_{50} \pm \mathrm{SFM}$ (standard error of the mean).

$\mathrm{E}=$ enkephalin. 


\section{H.I. Mosberg et al.}

properties of these analogs, conformationdependent ${ }^{1} H$ n.m.r. parameters were measured and are compared to those previously reported for [D-Pen $\left.{ }^{2}, \mathrm{D}-\mathrm{Pen}^{5}\right]$ enkephalin and [D-Cys ${ }^{2}, \mathrm{D}-\mathrm{Pen}^{5}$ ]enkephalin (4) in Table 2. As can be seen from Table 2, excellent agreement is observed between chemical shift and coupling constant values for [(3S)Me-D-Cys ${ }^{2}$. D-Pen ${ }^{5}$ enkephalin with the corresponding values for $\left[\mathrm{D}-\mathrm{Cys}^{2}, \mathrm{D}-\mathrm{Pen}{ }^{\mathrm{s}}\right]$ enkephalin and [D$\mathrm{Pen}^{2}, \mathrm{D}-\mathrm{Pen}^{5}$ ]enkephalin, indicating similar conformations among these three peptides. As is also apparent in Table 2, the Pen ${ }^{2} 3-$ methyl groups of [D-Pen $\left.{ }^{2}, \mathrm{D}-\mathrm{Pen}^{5}\right]$ enkephalin display a large chemical shift inequivalence arising from a ring current effect of the $\mathrm{Tyr}^{1}$ aromatic moiety which shifts one of these methyl resonances upfield (12). The apparently similar conformations of $\left[(3 S) \mathrm{Me}-\mathrm{D}-\mathrm{Cys}^{2}\right.$,
D-Pen $\left.{ }^{5}\right]$ enkephalin and [D-Pen ${ }^{2}$, D-Pen ${ }^{5}$ ]enkephalin and the finding that the $3 S$-methyl of residue 2 in the former peptide is seen at a similar chemical shift as the upfield shifted methyl resonance in the latter $(0.90$ p.p.m. $v$ s. 0.84 p.p.m.) allows the stereospecific assignment of the D-Pen ${ }^{2}$ 3-methyl resonances of [D-Pen ${ }^{2}$, D-Pen ${ }^{5}$ enkephalin. Thus, for [DPen $^{2}$, D-Pen ${ }^{5}$ ]enkephalin we conclude that the resonances at 1.48 p.p.m. and 0.84 p.p.m. are due to the pro- $R$ and pro- $S$ methyls, respectively, of the D-Pen ${ }^{2}$ residue. These assignments are in agreement with unequivocal assignments resulting from stereospecific deuteration of D-penicillamine and its incorporation into [D-Pen ${ }^{2}, \quad$ D-Pen $\left.{ }^{5}\right]$ enkephalin (13).

In contrast to $\left[(3 S) \mathrm{Me}-\mathrm{D}-\mathrm{Cys}^{2}, \mathrm{D}-\mathrm{Pen}^{5}\right]-$ enkephalin, [(3R)Me-D-Cys ${ }^{2}, \quad$ D-Pen $\left.{ }^{5}\right]-$

TABLE ?

Comparison of $H$ n.m.r. parameters of $\left[D-X^{2}, D-P e n^{5}\right]$

\begin{tabular}{|c|c|c|c|c|c|}
\hline Residue & $\delta_{z}$ & $\delta_{x+1}$ & $\mathrm{~J}_{\mathrm{YHT} / \mathrm{C} H}$ & & Ottier \\
\hline $\mathrm{Tyr}^{\prime}$ & $\begin{array}{ll}\text { a. } & 4.31 \\
\text { b. } & 4.39 \\
\text { c. } & 4.40 \\
\text { d. } & 4.15\end{array}$ & - & $\begin{array}{l}- \\
- \\
-\end{array}$ & Arom & $\begin{array}{l}7.14 ; 6.87 \\
7.16 ; 6.87 \\
7.14 ; 6.87 \\
7.14 ; 6.87\end{array}$ \\
\hline $2 X^{2}$ & $\begin{array}{l}4.72 \\
4.18 \\
4.58 \\
4.07\end{array}$ & $\begin{array}{l}8.26 \\
8.20 \\
8.40 \\
8.67\end{array}$ & $\begin{array}{l}7.3 \mathrm{~Hz} \\
7.8 \\
* * \\
* *\end{array}$ & $\mathrm{Me}=$ & $\begin{array}{l}- \\
1.48 ; 0.84 \\
0.90 \\
0.97\end{array}$ \\
\hline Gly & $\begin{array}{l}4.32: 3.53 \\
4.35: 3.54 \\
4.20: 3.54 \\
4.27: 3.39\end{array}$ & $\begin{array}{l}8.69 \\
8.52 \\
8.69 \\
8.85\end{array}$ & $\begin{array}{l}2.9: 8.1 \\
4.3: 8.4 \\
3.3: 8.4 \\
5.0: 7.2\end{array}$ & $\mathbf{J}_{x x^{\prime}}=$ & $\begin{array}{l}15.5 \mathrm{~Hz} \\
15.4 \\
15.7 \\
14.4\end{array}$ \\
\hline $\mathrm{Phe}^{+}$ & $\begin{array}{l}4.50 \\
4.52 \\
4.52 \\
4.55\end{array}$ & $\begin{array}{l}8.43 \\
8.47 \\
8.34 \\
8.64\end{array}$ & $\begin{array}{l}5.8 \\
6.0 \\
5.5 \\
5.1\end{array}$ & Arom $=$ & $\begin{array}{l}7.3 \\
7.3 \\
7.3 \\
7.3\end{array}$ \\
\hline D-Pen 5 & $\begin{array}{l}4.49 \\
4.38 \\
4.38 \\
4.33\end{array}$ & $\begin{array}{l}7.53 \\
7.40 \\
7.57 \\
7.55\end{array}$ & $\begin{array}{l}8.8 \\
8.6 \\
7.7 \\
5.5\end{array}$ & $\mathrm{Me}=$ & $\begin{array}{l}1.43 ; 1.32 \\
1.34: 1.29 \\
1.42: 1.33 \\
1.42: 1.40\end{array}$ \\
\hline
\end{tabular}

Values for: a. [D-Cys ${ }^{2}$. D-Pen $\left.{ }^{5}\right]$ enkephalin

b. [D-Pen $\left.{ }^{2}, D-P e n^{5}\right]$ enkephalin

c. [(3S)Me-b-Cys'. D-Pen"]enkephalin

d. $\left[(3 R) \mathrm{Me}-\mathrm{D}-\mathrm{Cys}^{2}, \mathrm{D}-\mathrm{Pen}^{5}\right] \mathrm{enkephalin}$

**Broad, unresolved resonance. 
enkephalin appears to assume a conformation different from [D-Pen $\left.{ }^{2}, \mathrm{D}-\mathrm{Pen}^{5}\right]$ enkephalin and $\left[\mathrm{D}-\mathrm{Cys}^{2}, \mathrm{D}-\mathrm{Pen}^{5}\right]$ enkephalin. ${ }^{1} \mathrm{H}$ n.m.r. evidence of this can be seen in the differences in the observed values of chemical shifts for $\mathrm{Tyr}^{1}$ and $\mathrm{D}-\mathrm{X}^{2} \alpha$ protons; $\mathrm{D}-\mathrm{X}^{2}$, $\mathrm{Gly}^{3}$, and $\mathrm{Phe}^{4}$ amide protons; and $\mathrm{D}-\mathrm{X}^{2} 3$ methyl protons and in the significant differences for the conformation-dependent coupling constants $\mathrm{J}_{\mathrm{NH} \times \mathrm{CH}}$ of the Gly and D-Pen ${ }^{5}$ residues as well as $J_{x *}$. for $\mathrm{Gly}^{3}$. The rather large number of differences observed suggest a considerably different conformation for $\left[(3 R) \mathrm{Me}-\mathrm{D}-\mathrm{Cys}^{2}, \quad\right.$ D-Pen $\left.{ }^{5}\right]$ enkephalin compared to the other analogs studied here. In particular, a distinct environment of the $\mathrm{D}-\mathrm{X}^{2}$ residue is evident from the considerably upfield shifted value of $\delta_{x}(4.07$ p.p.m.), which would otherwise be expected to lie between that observed for $\left[\mathrm{D}-\mathrm{Pen}^{2}, \mathrm{D}-\mathrm{Pen}^{5}\right]$ enkephalin and $\left[\mathrm{D}-\mathrm{Cys}^{2}, \mathrm{D}-\mathrm{Pen}^{5}\right]$ enkephalin, and from the upfield shifted 3-methyl resonance at 0.97 p.p.m., which, if in a similar environment as for [D-Pen $\left.{ }^{2}, \mathrm{D}-\mathrm{Pen}^{5}\right]$ enkephalin, would be expected at ca. $1.4-1.5$ p.p.m. It should be pointed out that the $\mathrm{D}-\mathrm{X}^{2}$ amide resonance for both $\left[(3 R) \mathrm{Me}-\mathrm{D}-\mathrm{Cys}^{2}, \mathrm{D}-\mathrm{Pen}^{5}\right]$ enkephalin and $\left[(3 S) \mathrm{Me}-\mathrm{D}-\mathrm{Cys}^{2}, \mathrm{D}-\mathrm{Pen}^{5}\right]$ enkephalin is broadened such that values for $\mathrm{J}_{\mathrm{NH} \times \mathrm{CH}}$ could not be extracted under the conditions employed. While this might seem to suggest conformational differences, in fact this broadening, which is due to rather fast exchange of the amide proton with solvent water, is also observed in $\left[\mathrm{D}-\mathrm{Cys}^{2}, \mathrm{D}-\mathrm{Pen}^{5}\right]$ enkephalin and $\left[D-P^{2}{ }^{2}\right.$, D-Pen $\left.{ }^{5}\right]$ enkephalin at only slightly higher temperatures (4).

The evidence for similar conformations among [D-Cys $\left.{ }^{2}, \mathrm{D}-\mathrm{Pen}^{5}\right]$ enkephalin, [D-Pen ${ }^{2}$, D-Pen $\left.{ }^{5}\right]$ enkephalin, and [ $(3 S) \mathrm{Me}-\mathrm{D}-\mathrm{Cys}^{2}, \mathrm{D}-$ Pen $\left.{ }^{5}\right]$ enkephalin allows their differing opioid receptor binding profiles to be explained in terms of steric effects of the 3-methyl groups. Since $\left[(3 S) \mathrm{Me}-\mathrm{D}-\mathrm{Cys}^{2}, \mathrm{D}-\mathrm{Pen}^{5}\right]$ enkephalin and $\left[\mathrm{D}-\mathrm{Cys}^{2}, \mathrm{D}-\mathrm{Pen}^{5}\right]$ enkephalin display similar mu receptor affinities while that of $\left[\mathrm{D}-\mathrm{Pen}^{2}, \mathrm{D}-\mathrm{Pen}^{5}\right.$ ]enkephalin is much lower, the $3 S$-methyl group of either [ $(3 S) \mathrm{Me}-\mathrm{D}-$ $\mathrm{Cys}^{2}$, D-Pen $]$ enkephalin or [D-Pen ${ }^{2}$, DPen ${ }^{5}$ ]enkephalin apparently has no effect on $\mathrm{mu}$ receptor binding and the reduced mu re- ceptor affinity of [D-Pen $\left.{ }^{2}, \mathrm{D}-\mathrm{Pen}^{5}\right]$ enkephalin is then most likely due to an adverse steric interaction between the D-Pen ${ }^{2}$ pro- $R$ methyl group with the mu receptor binding site. On the other hand, the delta receptor binding affinity of [(3S)Me-D-Cys ${ }^{2}$, D-Pen $\left.{ }^{5}\right]$ enkephalin is intermediate between that observed for $\left[\mathrm{D}-\mathrm{Pen}^{2}, \mathrm{D}-\mathrm{Pen}^{5}\right]$ enkephalin and $\left[\mathrm{D}-\mathrm{Cys}^{2}\right.$, D-Pen ${ }^{5}$ enkephalin. These results suggest that both the pro- $S$ and pro- $R$ methyl groups of the $D-P^{2}{ }^{2}$ residue of $\left[\mathrm{D}-\mathrm{Pen}^{2}, \mathrm{D}-\mathrm{Pen}^{5}\right.$ ] ${ }^{2}$ kephalin lead to adverse steric interactions with the delta receptor binding site. While these steric effects on delta receptor binding are modest, resulting in less than a threefold decrease in affinity, the steric interaction between the pro- $R$ D-Pen ${ }^{2}$ methyl group of [D-Pen ${ }^{2}, \mathrm{D}-\mathrm{Pen}^{5}$ ] ${ }^{\mathrm{C}}$ kephalin and the mu receptor leads to a 100 -fold decrease in affinity compared to $\left[\mathrm{D}-\mathrm{Cys}^{2}, \mathrm{D}-\mathrm{Pen}^{5}\right.$ ]enkephalin. Although [(3R)Me-D-Cys ${ }^{2}$, D-Pen $\left.{ }^{5}\right]$ enkephalin assumes an altered conformation and therefore can provide no further confirmation, the results described above present clear evidence for differential binding effects of the two D-Pen ${ }^{2} 3$-methyl groups of [D-Pen ${ }^{2}$, DPen $^{5}$ ]enkephalin.

\section{ACKNOWLEDGMENTS}

This work was supported by USPHS grants DA 03910 (H.I.M.), GM 36184 (R.W.W.), DA 02265 (H.A.), and MH 09267 (A.M.).

\section{REFERENCES}

1. Mosberg, H.I., Hruby, V.J., Hurst, R., Galligan, J.J., Burks, T.F., Gee, K. \& Yamamura. H.I. (1983) Life Sci. 32, 2565-2569

2. Mosberg, H.I., Hurst, R., Hruby, V.J., Galligan, J.J., Burks, T.F., Gee, K. \& Yamamura, H.I. (1983) in Peptides: Structure and Function, Proceedings of the Eighth American Peptide Symposium (Hruby, V.J. \& Rich, D.H., eds.), pp. 279-282

3. Mosberg, H.I., Hurst, R., Hruby, V.J., Gee, K., Yamamura, H.I., Galligan, J.J. \& Burks, T.F. (1983) Proc. Natl. Acad. Sci. US 80, 5871-5874

4. Mosberg, H.I. (1987) Int. J. Peptide Protein Res. 29, 282-288

5. Mosberg, H.I., Omnaas, J.R. \& Goldstein, A (1987) Mol. Pharmacol. 31, 599-602

6. Elliot, D.F. (1950) J. Chem. Soc. A, 62-68 


\section{H.I. Mosberg et al.}

7. Morell, J.L., Fleckenstein. P., \& Gross. E. (1977) J. Org. Chem. 42, 355-356

8. Moroder, L., Hallett, A., Wünsch, E.. Keller, O. \& Wersin. G. (1976) Hoppe-Severs Z. Physiol. Chem. 357, 1651-1653

9. Hoogmartens. J. Claes. P.J. \& Vanderhaeghe. H.V. (1974) J. Org. Chem. 39, 425-427

10. Handa, B.K., Lane, A.C., Lord, J.A.H.. Morgan. B.A., Rance, M.J.\& Smith. C.F. (1981) European J. Pharmacol. 70. 531-540

11. Gacel, G.. Fournie-Zaluski, M.-C. \& Roques, B.P. (1980) FEBS Lett. 118. 245-247

12. Mosberg. H.I. \& Schiller. P.W. (1984) Int. J.
Peptide Protein Res. 23, 462-466

13. Mosberg, H.I., Subramanian, P., Sobczyk, K., Crippen, G.M., Ramalingam, K. \& Woodard, R.W. (1987) Presented at the Tenth American Peptide Symposium, St. Louis, MO, May 1987

Address:

Dr. Henry 1. Mosberg

College of Pharmacy

University of Michigan

Ann Arbor, MI 48109-1065

USA 